\title{
Oxidative stress and its association with ST resolution and clinical outcome measures in patients with ST-segment elevation myocardial infarction (STEMI) undergoing primary percutaneous coronary intervention
}

\author{
Elmira Matin ${ }^{1}$, Samad Ghaffari ${ }^{*}$, Alireza Garjani ${ }^{2}$, Neda Roshanravan ${ }^{1}$, Somaieh Matin ${ }^{3}$, \\ Naimeh Mesri Alamdari ${ }^{1,4}$ and Naser Safaie ${ }^{1}$
}

\begin{abstract}
Objective: Reperfusion of ischemic myocardium generates oxidative stress, which itself can mediate myocardial injury. So, in this study, we investigated the level of oxidative stress markers and its association with clinical outcomes in patients with ST-segment elevation myocardial infarction (STEMI) undergoing primary percutaneous coronary intervention.

Results: As indicated in the results, Post MI (Myocardial Infarction) heart failure was significantly higher in the group A (11\% vs 4\%, $p=0.047)$. Complete STR (ST-segment resolution) was observed to be significantly higher in the group B (36\% vs $17 \%, p=0.006)$. The SOD (Superoxide dismutase) and GPX (Glutathione peroxidase) levels were significantly higher in the group B compared to the other group (1547.51 \pm 328.29 vs. $1449.97 \pm 246.06, p=0.019$ and $60.62 \pm 11.95$ vs $57.41 \pm 10.14, p=0.042$ ). The levels of GPX and SOD were shown to be directly related with complete STR and post PCI (Percutaneous coronary intervention)TIMI(Thrombolysis in Myocardial Infarction) flow 3 in the group $A(p=0.002$ and $p<0.01, p=0.005$ and $p<0.02$, respectively).
\end{abstract}

Keywords: Ischemia reperfusion injury, Oxidative stress, Myocardial infarction

\section{Introduction}

Cardiovascular disease is known as the leading cause of death worldwide [1]. Cardiovascular risk factors result in endothelial injury and propagate atherosclerosis [2]. Accordingly, acute myocardial infarction (MI) is one of the most prevalent forms of ischemic heart diseases [3]. The most important decision for a patient with STsegment elevation myocardial infarction (STEMI) is the

\footnotetext{
*Correspondence: ghafaris@gmail.com

${ }^{1}$ Cardiovascular Research Center, Tabriz University of Medical Sciences, Tabriz, Iran

Full list of author information is available at the end of the article
}

early and successful myocardial reperfusion by the use of thrombolytic therapy or primary percutaneous coronary intervention (PPCI), which has been shown as effective method on balancing the blood supply as well as demanding and improving the clinical outcome [4-6].

Various studies have indicated that, huge quantities of reactive oxygen species (ROS) are produced during reperfusion of the blood flow after MI [7, 8]. Consequently, these highly reactive species cause oxidative damage [9], which thereby lead to myocardial ischemia-reperfusion injury that can paradoxically reduce the beneficial effects of myocardial reperfusion $[10,11]$. Malondialdehyde (MDA), as lipid peroxidation

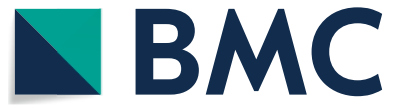

(c) The Author(s) 2020. This article is licensed under a Creative Commons Attribution 4.0 International License, which permits use, sharing, adaptation, distribution and reproduction in any medium or format, as long as you give appropriate credit to the original author(s) and the source, provide a link to the Creative Commons licence, and indicate if changes were made. The images or other third party material in this article are included in the article's Creative Commons licence, unless indicated otherwise in a credit line to the material. If material is not included in the article's Creative Commons licence and your intended use is not permitted by statutory regulation or exceeds the permitted use, you will need to obtain permission directly from the copyright holder. To view a copy of this licence, visit http://creativeco mmons.org/licenses/by/4.0/. The Creative Commons Public Domain Dedication waiver (http://creativecommons.org/publicdomain/ zero/1.0/) applies to the data made available in this article, unless otherwise stated in a credit line to the data. 
product, is known as one of the oxidative stress biomarkers [12, 13]. Beyond that superoxide dismutase (SOD) and glutathione peroxidase (GPX) are the first well- known line enzymes of the antioxidant defense $[14,15]$. Correspondingly, some studies have shown the role of oxidant-antioxidant imbalance in the pathogenesis of myocardial ischemia and reperfusion injury. Moreover, antioxidant protects the cellular and subcellular membranes against the oxidative stress injury. It was indicated that the increased activity of total antioxidant capacity reduces the damages produced by the enhancement of lipid peroxidation, which may act by counteracting the harmful products $[16,17]$.

Thrombolysis in myocardial infarction (TIMI) flow is considered as the most valuable indicator of the epi cardial coronary flow. However, electrocardiographic $\mathrm{ST}$ resolution is a valuable marker of the improved myocardial reperfusion in microvascular system and also at the cellular level [18].

In this study, we investigated the probable role of stress oxidative markers (MDA, SOD, GPX, and Total antioxidant capacity (TAC)) among STEMI patients undergoing primary PCI based on Coronary TIMI flow, as well as their associations with in-hospital outcome. Therefore, in this study, we aimed to investigate the levels of MDA, SOD, GPX, and Total antioxidant capacity (TAC) as well as their relationships with ST resolution and clinical outcomes among STEMI patients undergoing primary PCI based on Coronary TIMI flow.

\section{Main text \\ Methods \\ Methods and materials}

This cross-sectional study was conducted in 2018on patients with STEMI in the first $6 \mathrm{~h}$ after their admission in the cardiology department at Madani Hospital, Tabriz, Iran.

The inclusion criteria were having resting chest pain for more than 20 min, showing variations in ECG with STsegment elevations greater than $2 \mathrm{~mm}$ in precordial leads and greater than $1 \mathrm{~mm}$ in limb leads, and having serum troponin or CK-MB levels at least two-fold of the upper limit of normal range regarding the laboratory references.

The exclusion criteria were also as follows: having Left Bundle Branch Block, late presentation ( $>6 \mathrm{~h}$ ), using pace-maker, having the history of Heart failure or rescue $\mathrm{PCI}$, chronic disease, malignancy, and being a candidate for emergency Coronary Artery Bypass Graft. Among the patients scheduled for primary PCI after matching with the study protocol, the first 100 consecutive patients with TIMI flow $<2$ were enrolled in the group $\mathrm{A}$ and the first 100 patients with TIMI flow $\geq 2$ were enrolled in the group B (Fig. 1). The written consent as well as a complete physical examination were obtained from the included patients. Electrocardiograms were recorded once on arrival and once $90 \mathrm{~min}$ after Primary PCI. STR (ST-segment resolution) was measured by passing $90 \mathrm{~min}$ from primary angioplasty at the same way to the maximal ST elevation in pre-angioplasty electrocardiogram. Mortality, arrhythmias, and post MI heart failure

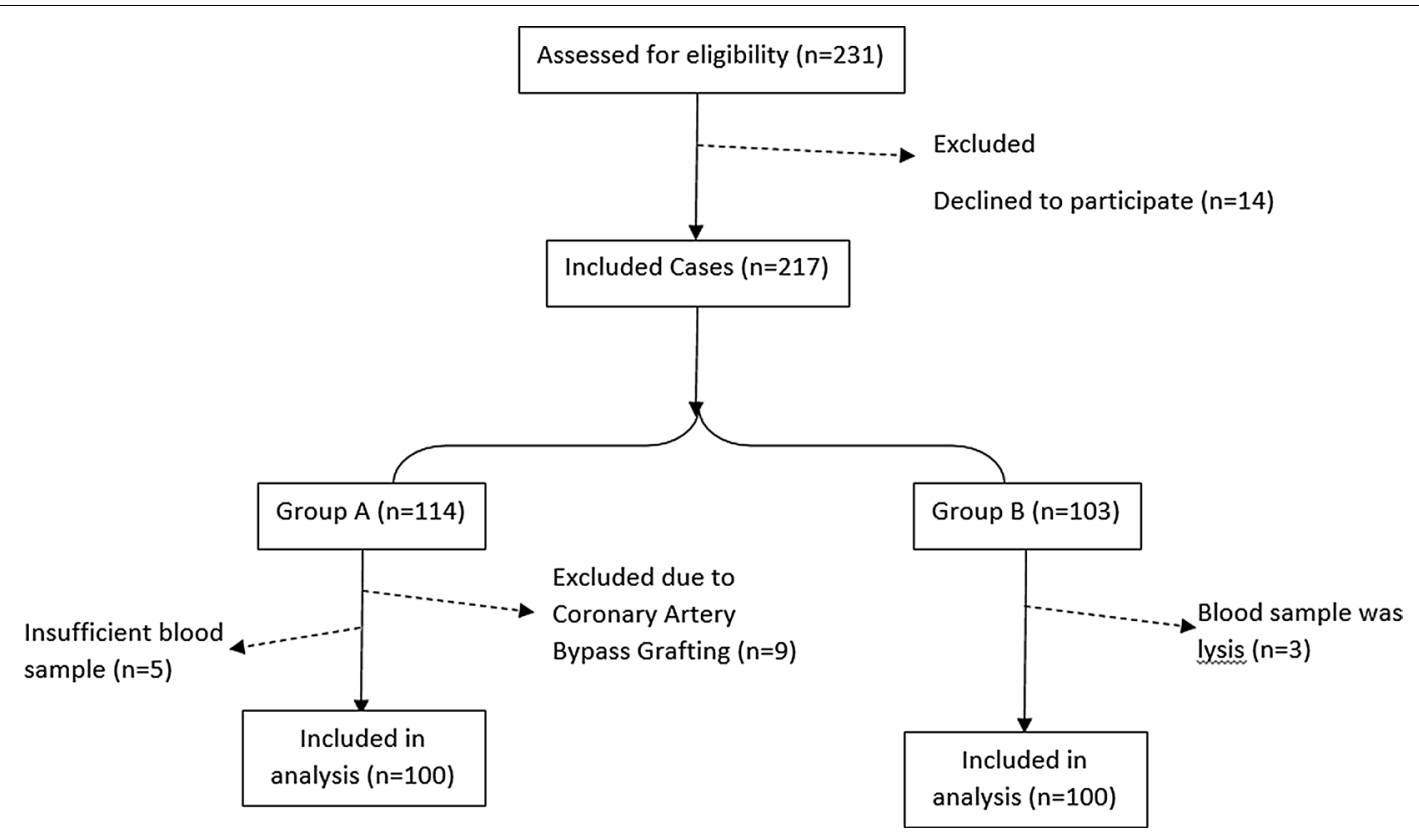

Fig. 1 The flow diagram of the study and patients allocations in groups 
were investigated as hospital outcomes. Those patients with a Left ventricular ejection fraction (LVEF) $<40 \%$ at the time of discharge and rales in the lungs auscultation or congestion in Chest X-Ray (in terms of the American Heart Association guideline) [19] were considered as patients with heart failure. This study was ethically approved in the Research Department of Tabriz University of Medical Sciences (Iran) under the code of 60,109.

\section{Biochemical information}

After an overnight fasting of $12 \mathrm{~h}$, five $\mathrm{mL}$ of venous blood samples were taken from each one of the participants. The obtained samples were centrifuged for $10 \mathrm{~min}$ at $1500 \mathrm{rpm}$ to separate the serum and then kept at $-80{ }^{\circ} \mathrm{C}$ for MDA, SOD, GPX, and TAC tests. Afterward, RASOD kit (Randox, lab.crumlin.UK) and RANSEL kits (Randox, lab.crumlin.UK) were used for the assessment of SOD, GPX, TAC, and MDA levels [20].

\section{Data analysis and statistical methods}

The distribution of the data was checked using Kolmogorov- Smirnov test. The independent sample t-test was also used for comparing these two groups. Thereafter, Pearson coefficient correlation was used to evaluate the relationships among SOD, GPX, levels and the rate of ST-R. The results were then reported in the form of mean \pm standard deviation. In this regard, IBM SPSS Statistics (ver.23) was applied to analyze all the obtained data. The significance level was considered as 0.05 for all of the tests.

\section{Results}

In this study, 200 STEMI patients were investigated. Accordingly, no significant differences were found between these two groups regarding demographic and risk factors variables (Table 1).

Moreover, there was no significant difference between the two groups regarding serum levels of MDA and TAC. However, SOD and GPX levels were also observed to be significantly higher in the group $B$ as compared to the group A (Table 2).

ST segment resolution was divided into three categories as follows: I. no response to treatment (ST-R levels $<50 \%$ ), II. partial response to the treatment $(50 \% \leq$ ST-R levels $<70 \%)$, and III. complete response to the treatment (ST-R levels $\geq 70 \%$ ) [21]. By investigating the relationship among SOD and GPX levels and the rate of ST-R, it was revealed that in the group A, both of the variables were associated with the rate of ST-R, while in group B, only the level of GPX was related to the rate of ST- resolution (Additional file 1: Table S1).

These two groups were not significantly different in terms of death and arrhythmia. However, the difference
Table 1 Comparison of demographic and baseline information and risk factors of CAD of Groups

\begin{tabular}{|c|c|c|c|}
\hline Variable & $\begin{array}{l}\text { Group } \\
A(n=100)\end{array}$ & $\begin{array}{l}\text { Group B } \\
(n=100)\end{array}$ & p-value* \\
\hline Age, years & $60.01 \pm 12.3$ & $61.55 \pm 11.32$ & $p>0.05$ (NS) \\
\hline $\begin{array}{l}\text { Gender, male } \\
\text { n (\%) }\end{array}$ & $80(70)$ & $73(73)$ & $p>0.05$ (NS) \\
\hline $\begin{array}{l}\text { Hypertension, } \\
n(\%)\end{array}$ & $62(62)$ & $51(51)$ & $p>0.05$ (NS) \\
\hline $\begin{array}{l}\text { Diabetes mellitus, } \\
\text { n (\%) }\end{array}$ & $33(33)$ & $24(24)$ & $p>0.05$ (NS) \\
\hline $\begin{array}{l}\text { Hyperlipidemia, } \\
\text { n(\%) }\end{array}$ & $54(54)$ & $43(43)$ & $p>0.05$ (NS) \\
\hline Smoking, n (\%) & $35(35)$ & $33(33)$ & $p>0.05$ (NS) \\
\hline $\begin{array}{l}\text { Family history, } \\
\mathrm{n}(\%)\end{array}$ & $32(32)$ & $27(27)$ & $p>0.05$ (NS) \\
\hline $\begin{array}{l}\text { Anterior STEMI, } \\
\mathrm{n}(\%)\end{array}$ & $61(61)$ & $56(56)$ & $p>0.05$ (NS) \\
\hline $\begin{array}{l}\text { Lateral STEMI, } \\
\text { n (\%) }\end{array}$ & $5(5)$ & $6(6)$ & $p>0.05$ (NS) \\
\hline $\begin{array}{l}\text { Inferior RV STEMI, } \\
\text { n (\%) }\end{array}$ & $9(9)$ & $15(15)$ & $p>0.05$ (NS) \\
\hline $\begin{array}{l}\text { Inferior STEMI, } \\
\text { n (\%) }\end{array}$ & $25(25)$ & $23(23)$ & $p>0.05$ (NS) \\
\hline
\end{tabular}

NS, not significant, Group A: TIMI flow $<2$, Group B: TIMI flow $\geq 2$

*p-value was reported based on Chi-Square test \& Independent sample t test

Table 2 The average serum levels of biochemical factors in group $A$ and $B$ (mean $\pm S D)$

\begin{tabular}{lccl}
\hline Variable & Group A $(\mathbf{n}=\mathbf{1 0 0})$ & Group B $(\mathbf{n}=\mathbf{1 0 0})$ & $\mathbf{p}$-value \\
\hline MDA $(\mathrm{nmol} / \mathrm{ml})$ & $2.33 \pm 0.76$ & $2.22 \pm 0.82$ & 0.133 \\
TAC $(\mathrm{mmol} / \mathrm{l})$ & $1.73 \pm 0.4$ & $1.65 \pm 0.4$ & 0.322 \\
$\mathrm{SOD}(\mu / \mathrm{g} \mathrm{Hb})$ & $1449.97 \pm 246.06$ & $1547.51 \pm 328.29$ & $0.019^{*}$ \\
$\mathrm{GPX}(\mu / \mathrm{g} \mathrm{Hb})$ & $57.41 \pm 10.14$ & $60.62 \pm 11.95$ & $0.042^{*}$ \\
\hline
\end{tabular}

SD: standard deviation, SOD: superoxide dismutase, GPX: Glutathione Peroxidase, MDA: Malondialdehyde, TAC: Total anti-oxidant capacity ${ }^{*} p<0.05$ in based on independent samples $t$-test between two groups Group A: TIMI flow $<2$, Group B: TIMI flow $\geq 2$

between these two groups was turned out to be significant in terms of heart failure. The rate of complete ST-R was higher in the group B compared to that of the other group, which showed a significant difference between them. In addition, we observed a higher rate of TIMI 3 flow after PCI in the group B compared to group A (Additional file 1: Table S2).

\section{Discussion}

The principal findings of this study were the higher level of SOD and GPX in patients with TIMI flow $\geq 2$. Beyond that Post MI heart failure was significantly higher in patients with TIMI flow $<2$. The higher level of complete 
STR in patients with TIMI flow $\geq 2$ was other finding of this study.

The disruption in the blood flow and endothelial dysfunction, caused by the changes in the ion channels and the increased level of oxidative stress, may consequently lead to the formation of plaques in the coronary arteries [22]. In this regard, reactive oxygen species are considered as the main initiators of myocardial damages during reperfusion process [14]. Two of the antioxidant enzymes, named SOD and GPX play important roles in supporting and protecting cells against oxidative damages $[23,24]$. Previous studies have indicated that in those patients with occluded arteries, due to the generation of reactive oxygen species that is the result of inflammations induced by tissue damages, primary PCI causes more damages [15]. Our study indicated that the serum levels of oxidative markers are significantly related to the severity of myocardial infarction and myocardial dysfunction. This finding is consistent with the findings of some previous studies [25, 26]. Furthermore, in this study, it was found that, the incidence rate of ventricular dysfunction was lower in the group with TIMI $\geq 2$ compared to the other group. The main reason of this result might be the higher levels of endogenous antioxidant enzymes like SOD and GPX, which protect the heart against reperfusion-induced damages [25, 27]. However, in our study, the two patients' groups were not found to be significantly different in terms of the incidence of some complications such as arrhythmia and mortality.

One of the criteria that is considered in determining the level of response to treatment and the restoration of blood flow is ST-segment resolution [28]. Moreover, STsegment resolution is a simple sign of myocardial reperfusion, which has been shown to be associated with left ventricular function recovery as well as mortality $[14,29]$. In this regard, various studies have demonstrated that if ST-segment does not return to its normal condition up to 90 min after PCI, so it can be considered as a unfavorable prognosis [26, 30,31]. Researchers in various studies have asserted that the lack of ST-segment resolution is the indicator of a perfusion defect in the myocardial tissue [29]. Our study have also indicated that the rate of complete ST-segment resolution to the baseline was lower in the patients of the TIMI $<2$ group $(\mathrm{STR} \geq 70 \%)$ compared to the patients in the TIMI $\geq 2$ group, which can be explained by the induced myocardial dysfunction resulted from the generation of more free radicals [20].

In a previous study, Kammler et al. reported that, after PCI, the patients with TIMI flow of equal to 2 or less than 2 showed some adverse clinical complications during their hospitalization period as well as after 6-month follow-up from the time being discharged from the hospital [25]. Other studies have also indicated that the decreased blood supply by the coronary arteries after primary PCI is accompanied with adverse clinical outcomes [27, 32]. However, it should also be noted that some other factors such as age, clinical manifestations, comorbidities, and the location of myocardial infarction play critical roles in the final outcome of STEMI patients, as candidates for primary PCI $[29,31]$.

In the present study, lipid peroxidation was evaluated by measuring MDA level. In addition, the antioxidant activity was also assessed via measuring TAC [23]. No significant differences were observed between these two study groups in terms of their MDA and TAC levels. However, this issue requires further assessments in future studies.

In a study, it was observed that following Remote Ischemic Post Conditioning (RIPC) during primary PCI, the level of antioxidants has significantly increased, while the level of MDA has significantly decreased compared to the control group. Accordingly, these findings revealed the beneficial effects of RIPC on decreasing the reperfusion-induced damages [20].

The analysis of various studies revealed the fact that the relationships among the oxidative stress, antioxidant markers, and myocardial infarction are mixed. Moreover, some studies have indicated that high levels of these markers in patients are associated with myocardial infarction, while some others have rejected the existence of such associations $[25,28,33]$. Correspondingly, this might be due to the fact that the levels of oxidative stress markers depend on various factors such as the duration of the appearance of symptoms and comorbidities like diabetes, as well as the other chronic diseases [20, 23]. On the other hand, these biomarkers may be simply considered as a marker of severe injury, so performing further studies by matching their levels with the enzymatic infarct size or cardiac MR findings may be helpful to test this hypothesis.

\section{Conclusion}

The findings of this study indicated that antioxidant enzymes levels in patients with STEMI are significantly associated with coronary artery stenosis and the level of responses to treatment. However, such relationships were not observed regarding the TAC and MDA levels. The imbalance between the production of free radicals and antioxidant defense systems was shown to be strongly associated with cardiovascular disease and its unfortunate outcome.

\section{Limitations}

Considering the limitations of the present study in measuring the levels of all antioxidant substances (selenium, vitamin C, etc.), it seems that performing further 
studies is necessary. Future studies with large sample size and by parallel measuring the levels of other antioxidant substances and some inflammatory factors like hs-CRP, might be helpful for having more definitive conclusions.

\section{Supplementary information}

Supplementary information accompanies this paper at https://doi. org/10.1186/s13104-020-05350-5.

Additional file 1: Table S1. Comparison SOD and GPX levels and the rate of ST-R between the two groups. Table S2. Hospital outcomes, complete response to treatment and post $\mathrm{PCI}$ TIMI.

\section{Abbreviations}

MI: Acute myocardial infarction; STEMI: ST-segment elevation myocardial infarction; PPCl: Primary percutaneous coronary intervention; ROS: Reactive Oxygen Species; MDA: Malondialdehyde; SOD: Superoxide dismutase; GPX: Glutathione peroxidase; TAC: Total antioxidant capacity; TIMI flow: Thrombolysis in myocardial infarction flow; LVEF: Left ventricular ejection fraction; hs-CRP: High sensitive C Reactive Protein.

\section{Acknowledgements}

The authors thank Research Vice Chancellor of Tabriz University of Medical Sciences for financial support. Furthermore, authors would like to thank all of the participants in the study as well as other friends and colleagues who cooperated in conducting this research.

\section{Authors' contributions}

All of the authors contributed equally. The contributions of authors are as fallow: EM: Provition of the study materials and equipment, Data analysis, draft preparation, SG: Project administration, Conceptualization, supervision, AG: Data validating, Study consultation, NR: Reviewing, Data validating, SM: Data analysis and data handling: NMA and NS: Draft preparation, Data handling. All authors read and approved the final manuscript.

\section{Funding}

No funding received for this study.

\section{Availability of data and materials}

The datasets used and/or analyzed during the current study are available from the corresponding author on reasonable request.

\section{Ethics approval and consent to participate}

The written consent was obtained from participants of study. This study was approved by the Research and Ethics Committee of the Cardiovascular Research Center, Shahid Madani Medical \& Training Hospital, Tabriz University of Medical Sciences, Iran (Ethic Code: IR.TBZMED.REC.1395.94).

\section{Consent for publication}

Not applicable.

\section{Competing interests}

Authors have no conflict of interest.

\author{
Author details \\ ${ }^{1}$ Cardiovascular Research Center, Tabriz University of Medical Sciences, Tabriz, \\ Iran. ${ }^{2}$ Department of Pharmacology, School of Pharmacy, Tabriz University \\ of Medical Sciences, Tabriz, Iran. ${ }^{3}$ Department of Internal Medicine, School \\ of Medicine, Ardabil University of Medical Sciences, Ardabil, Iran. ${ }^{4}$ Depart- \\ ment of Nutrition, School of Public Health, Iran University of Medical Sciences, \\ Tehran, Iran.
}

Received: 6 September 2020 Accepted: 21 October 2020 Published online: 11 November 2020

\section{References}

1. Hausenloy DJ, Botker HE, Engstrom T, Erlinge D, Heusch G, Ibanez B, et al. Targeting reperfusion injury in patients with ST-segment elevation myocardial infarction: trials and tribulations. Eur Heart J. 2016. https://doi. org/10.1093/eurheartj/ehw145.

2. Goldberg RJ, Tisminetzky M, Tran HV, Yarzebski J, Lessard D, Gore JM. Decade long trends (2001-2011) in the incidence rates of initial acute myocardial infarction. Am J Cardiol. 2019. https://doi.org/10.1016/j.amjca rd.2018.10.002.

3. Charfeddine S, Abid L, Ali ZB, Yousfi C, Gtif I, Hammami R, et al. Oxidative stress and left ventricular dysfunction following acute coronary syndrome. Arch Cardiovasc Dis. 2020. https://doi.org/10.1016/j.acvds p.2019.09.038.

4. Bandara R, Medagama A, Munasinghe R, Dinamithra N, Subasinghe A, Herath J, et al. Management and outcomes of acute ST-segmentelevation myocardial infarction at a tertiary-care hospital in Sri Lanka: an observational study. BMC Cardiovasc Disorders. 2015. https://doi. org/10.1186/1471-2261-15-1.

5. Yellon DM, Hausenloy DJ. Myocardial reperfusion injury. N Engl J Med. 2007. https://doi.org/10.1056/NEJMra071667.

6. Polańska-Skrzypczyk M, Karcz M, Rużyłło W, Witkowski A. Successful primary percutaneous coronary intervention determines the very long-term prognosis in ST-segment elevation myocardial infarction even in survivors of the acute phase. The ANIN Myocardial Infarction Registry. Postepy Kardiol Interwencyjnej. 2019. https://doi.org/10.5114/aic.2019.87881.

7. Zhou T, Chuang C-C, Zuo L. Molecular characterization of reactive oxygen species in myocardial ischemia-reperfusion injury. Biomed Res Int. 2015. https://doi.org/10.1155/2015/864946.

8. Raedschelders K, Ansley DM, Chen DD. The cellular and molecular origin of reactive oxygen species generation during myocardial ischemia and reperfusion. Pharmacol Ther. 2012. https://doi.org/10.1016/j.pharmthera .2011.11.004.

9. Bice JS, Jones BR, Chamberlain GR, Baxter GF. Nitric oxide treatments as adjuncts to reperfusion in acute myocardial infarction: a systematic review of experimental and clinical studies. Basic Res Cardiol. 2016. https ://doi.org/10.1007/s00395-016-0540-y.

10. He S, Wang X, Chen A. Myocardial ischemia/reperfusion injury: the role of adaptor proteins Crk. Perfusion. 2017. https://doi.org/10.1177/02676 59117691813.

11. Danchin N, Puymirat E, Cayla G, Cottin Y, Coste P, Gilard M, et al. One-year survival after st-segment-elevation myocardial infarction in relation with prehospital administration of dual antiplatelet therapy: The FAST-MI Program. Circ Cardiovasc Interv. 2018. https://doi.org/10.1161/CIRCINTERV ENTIONS.118.007241.

12. Matin S, Nemati A, Ghobadi H, Alipanah-Moghadam R, Rezagholizadeh $\mathrm{L}$. The effect of conjugated linoleic acid on oxidative stress and matrix metalloproteinases 2 and 9 in patients with COPD. Int J Chron Obstruct Pulmon Dis. 2018. https://doi.org/10.2147/COPD.S155985.

13. Badalzadeh R, Mohammadi M, Najafi M. Diabetes mellitus abolishes the cardioprotective effect of ischemic postconditioning against ischemia/ reperfusion injury in rat: Role of lipid peroxidation. Clin Biochem. 2011. https://doi.org/10.1016/j.clinbiochem.2011.08.128.

14. Griendling KK, FitzGerald GA. Oxidative stress and cardiovascular injury: part I: basic mechanisms and in vivo monitoring of ROS. Circulation. 2003. https://doi.org/10.1161/01.CIR.0000093660.86242.BB.

15. Hekmat M, Taherkhan M, Saraiani M, Sadeghi R, Naser V. Evaluation of independent impact of ST-segment resolution on outcome of patients with myocardial infarction. Res Med. 2011;35:152-6.

16. Börekçi A, Gür M, Türkoğlu C, Selek Ş, Baykan AO, Şeker T, et al. Oxidative stress and spontaneous reperfusion of infarct-related artery in patients with ST-segment elevation myocardial infarction. Clin Appl Thromb Hemost. 2016. https://doi.org/10.1177/1076029614546329.

17. Kurian GA, Rajagopal R, Vedantham S, Rajesh M. The role of oxidative stress in myocardial ischemia and reperfusion injury and remodeling: revisited. Oxid Med Cell Longev. 2016. https://doi. org/10.1155/2016/1656450.

18. Jia R, Nie X, Li H, Zhu H, Pu L, Li X, et al. Impact of attenuated plaques on TIMI grade flow and clinical outcomes of coronary artery disease patients: a systematic review and meta analysis. J Thorac Dis. 2016. https://doi. org/10.21037/jtd.2016.02.51. 
19. Yancy CW, Jessup M, Bozkurt B, Butler J, Casey DE, Colvin MM, et al. ACC/ AHA/HFSA focused update of the 2013 ACCF/AHA guideline for the management of heart failure: a report of the American College of Cardiology/ American Heart Association Task Force on Clinical Practice Guidelines and the Heart Failure Society of America. J Am Coll Cardiol. 2017. https://doi. org/10.1016/j.jacc.2017.04.025.

20. Lotfollahi H, Mohammadi M, Ghaffari S, Badalzadeh R, Sohrabi B, Aslanabadi $\mathrm{N}$, et al. Effect of remote ischemic post-conditioning on oxidative stress in blood of STEMI patients treated with primary angioplasty. J Cardiovasc Thorac Res. 2016. https://doi.org/10.15171/jcvtr.2016.24.

21. Armstrong P. Uwe Zeymer1, Kurt Huber2, Yuling Fu3, Allan Ross4, Christopher Granger5, Patrick Goldstein6, Frans van de Werf7 and. Eur Heart J Acute Cardiovasc Care. 2012. https://doi.org/10.1177/2048872612447069.

22. Zhang R, Brennan M-L, Shen Z, MacPherson JC, Schmitt D, Molenda CE, et al. Myeloperoxidase functions as a major enzymatic catalyst for initiation of lipid peroxidation at sites of inflammation. J Biol Chem. 2002. https://doi.org/10.1074/jbc.M209124200.

23. Hong Y. Burden of cardiovascular disease in Asia: big challenges and ample opportunities for action and making a difference. Clin Chem. 2009. https://doi.org/10.1373/clinchem.2009.125369.

24. Boukhris M, Bousselmi R, Tomasello SD, Elhadj Zl, Azzarelli S, Marzà F, et al. Mechanical post-conditioning in STEMI patients undergoing primary percutaneous coronary intervention. J Saudi Heart Assoc. 2015. https:// doi.org/10.1016/j.jsha.2014.11.001.

25. Kammler J, Kypta A, Hofmann R, Kerschner K, Grund M, Sihorsch K, et al. TIMI 3 flow after primary angioplasty is an important predictor for outcome in patients with acute myocardial infarction. Clin Res Cardiol. 2009. https://doi.org/10.1007/s00392-008-0735-9.

26. Mrdovic I, Mitrovic P, Matic D, Vasiljevic Z, Matic M, Asanin M. Oxidative stress markers predict early left ventricular systolic dysfunction after acute myocardial infarction treated with primary percutaneous coronary intervention. Advances. 2018. https://doi.org/10.17219/acem/64464.

27. Montecucco F, Carbone F, Schindler TH. Pathophysiology of ST-segment elevation myocardial infarction: novel mechanisms and treatments. Eur heart J. 2015. https://doi.org/10.1093/eurheartj/ehv592.
28. Zeymer U, Vogt A, Zahn R, Weber MA, Tebbe U, Gottwik M, et al. Predictors of in-hospital mortality in 1333 patients with acute myocardial infarction complicated by cardiogenic shock treated with primary percutaneous coronary intervention ( $\mathrm{PCl}$ ) Results of the primary PCI registry of the Arbeitsgemeinschaft Leitende Kardiologische Krankenhausärzte (ALKK). Eur heart J. 2004. https://doi.org/10.1016/j.ehj.2003.12.008.

29. Pasupathy $S$, Homer-Vanniasinkam S. Ischaemic preconditioning protects against ischaemia/reperfusion injury: emerging concepts. Eur J Vasc Endovasc Surg. 2005. https://doi.org/10.1016/j.ejvs.2004.11.005.

30. Kozieradzka A, Kamiński K, Dobrzycki S, Nowak K, Musiał W. Original article TIMI Risk Score accurately predicts risk of death in 30-day and one-year follow-up in STEMI patients treated with primary percutaneous coronary interventions. Kardiol Pol. 2007. https://doi.org/10.111 1/j.1540-8183.2012.00763.x.

31. Kamiński K, Bonda T, Wojtkowska I, Dobrzycki S, Kralisz P, Nowak K, et al. Oxidative stress and antioxidative defense parameters early after reperfusion therapy for acute myocardial infarction. Acute Card Care. 2008. https ://doi.org/10.1080/17482940701744334.

32. Brener SJ, Moliterno DJ, Aylward PE, van't Hof AW, Ruźyllo W, O'Neill WW, et al. Reperfusion after primary angioplasty for ST-elevation myocardial infarction: predictors of success and relationship to clinical outcomes in the APEX-AMI angiographic study. Eur heart J. 2008. https://doi. org/10.1093/eurheartj/ehn125.

33. Espinola-Klein C, Rupprecht HJ, Bickel C, Schnabel R, Genth-Zotz S, Torzewski M, et al. Glutathione peroxidase-1 activity, atherosclerotic burden, and cardiovascular prognosis. Am J Cardiol. 2007. https://doi. org/10.1016/j.amjcard.2006.10.041.

\section{Publisher's Note}

Springer Nature remains neutral with regard to jurisdictional claims in published maps and institutional affiliations.
Ready to submit your research? Choose BMC and benefit from:

- fast, convenient online submission

- thorough peer review by experienced researchers in your field

- rapid publication on acceptance

- support for research data, including large and complex data types

- gold Open Access which fosters wider collaboration and increased citations

- maximum visibility for your research: over 100M website views per year

At BMC, research is always in progress.

Learn more biomedcentral.com/submissions 